\title{
PIONEER
}

VOLUME 13, Issue 2, December 2021: 260 - 270

\section{IDENTIFYING STUDENTS' PROBLEMS ON CRITICAL THINKING AS A WAY TO FOSTER HIGHER ORDER THINKING SKILLS}

\author{
${ }^{1}$ Andi Dian Rahmawan* \\ Universitas PGRI Yogyakarta, Indonesia \\ ${ }^{1}$ andi@upy.ac.id \\ ${ }^{2}$ Eko Perianto \\ Universitas PGRI Yogyakarta, Indonesia \\ ²ekoperianto@gmail.com
}

*Corresponding author: andi@upy.ac.id

Received : November 12, 2021 Revised : December 8, 2021

Accepted : December 25, $2021 \quad$ Published : December 30, 2021

\begin{abstract}
Students in the old days were not taught to think for themselves in a logical, systematic, and coherent way. They simply regurgitated lectures and text materials back to the teachers. Integrating the traditional method of teaching with the critical thinking model would be the better alternative for teachers to prepare students to solve problems in the future. The samples of this study are the whole graduated students from English Department Students at University of PGRI Yogyakarta, starting from 2018-2021. It is descriptive qualitative research, focusing on the assessment matrix in the assessment of thesis examination by giving in-depth highlight on trends. From the data analyses, it is inferred that gender would give less impact to the successfulness of developing Critical Thinking. On the other hand, the autonomous learning would never give the same good results from one condition to another. It is revealed from the finding that learning with peers impacts better than the autonomous learning and learning with teachers.
\end{abstract}

Keywords: learning preferences, research papers, solving problems, student's critical thinking

\section{INTRODUCTION}

In the nowadays classroom which analyzing and synthesizing are explicitly pursued, students are dealing with common core of skills such as problem solving, decision making, inference, divergent thinking, evaluative thinking, reasoning and transfer which is called as higher-order cognitive skills, or simply as Critical Thinking skills (OCampo \& Belecina, 2018). As it has been stated clearly that students are required to distinguish correct and false information, and be multilingual and globally environmentally sensitive. All of these are need to take participation effectively in 
communication, upgrade the level of education level, and to be successful in the future competition (Handayani, 2016).

Knowledge background would be a fundamental requirement to do such critical thinking, it is supported by dependent deep structure and practices such as taking participation in discussion and proper sufficient reading which is in fact our students are lack of it (Amin \& Ardiansyah, 2018). The problems do not come alone from the students, teachers might have lack and improper understanding of the critical thinking. More than that, Critical Thinking is not easy to be taught and well internalized since the existence of different quality of its teaching between South-East and Western students. The South East ones are generally lack an understanding of the requirements of analysis and critique. Our students have heard the concepts of Critical Thinking, but often disconcerted by what it means and what it entails. Another social condition factor is the pandemic of Covid-19 which forces teachers to conduct teaching learning processes online. It is argued that it is merely changing the medium of delivery materials; teachers should have the carefully considered method of delivering values and skills, including the Critical Thinking. Teachers should be aware that deficiency does exist in the students' motivation, selfefficacy, and Critical Thinking dispositions when students are exposed to online teaching (Dewi, 2021). ; The offline one also brings problem that is when the class enrolment is huge. It decreases the teachers' attention to the various students' motivation, characteristics, learning styles, gender, age, and academic abilities (Barnaba \& Rahmawan, 2019; Mahanal, 2019; Zetriuslita et al., 2016).

Related to some solutions that have been offered to the above research, it is an urge to conduct research on identifying students' trends on Critical Thinking which would be connected to their social backgrounds such as age, sex, students' learning preferences, and willingness to take participation in class discussion. The focus of the study would be highly paid to the ones who get the lowest scores, as way to describe what factors that would succeed the process of developing critical thinking revealed from the scores of 7 points of thesis examination matrix. It is expected that the teachers would pay more attention to those students' differences, so that there would be no more students who possess less critical thinking ability compared to other ones. 


\section{REVIEW OF LITERATURE}

There are various innovations regarding how critical thinking ability is implemented in a classroom. The guided Problem-Based Learning was found to be effective for students' learning, although the results are not always the same across disciplines which is mostly influenced by motivation (Bashith \& Amin, 2017; Choi et al., 2014; Kumar \& Refaei, 2017; Maulidiya \& Nurlaelah, 2018; Nargundkar, 2014; Yuan, 2018). In this approach, students are expected to solve problems in reversed books that have been designed to develop students' critical thinking. Another study imposed the frequent and explicit teacher modeling of critical thinking skills, such as summarizing concepts by analyzing, justifying and defending ideas, making decisions, and finally solving real-world problems (Pasaribu \& Ariyani, 2019; Živkovic, 2016). The teachers' model should be in the form of discussion that allows students to increase their participation. Moreover, it is better for teachers to pick limited and selective discussion problems which required in-depth students' participation to do what is called as scaffolding during the class rather than to use standard books which cover every conceivable theory, principle and subject poorly (Nangimah, 2020). It significantly benefits students that they can ask series questions by identify and evaluate key phrases, assumptions, evidence, cause and effect arguments, and controversies both the offline and online classroom. On the other hand, teachers may give them constant written and oral feedbacks (Carvalho et al., 2015).

Some teachers focus too much to the subject materials they are teaching, but reluctant to evaluate, revise, and integrate their instructional method to Critical Thinking. This is worse by those teachers who impose questions, during classroom activities that require only lower order thinking or basic recall. This kind of questions would never develop students' critical thinking (Nappi, 2017). Teachers need the more carefully considered questions which are utilized Bloom's taxonomies as to analyze, apply, and create. As the result, it leads students to deeper understanding. The process of internalizing the Critical Thinking to students can be conducted also outside the classroom, this is called as service learning experiences. This kind of activity enhances students' communication skills, strengthen critical thinking abilities, develop civic responsibility, and foster a sense of caring for others in the way that students develop independent learning, decision made, self-esteem, self-reflection environments and 
community-based partnership crucial to the preparation of their future carriers (Nelson \& Crow, 2014).

\section{METHOD}

This research employs the descriptive qualitative method highlighting the trends of the critical thinking abilities among graduated students of English Department (PBI) at Universitas PGRI Yogyakarta. Since PBI has just been established in 2013, there are three academic years of graduation $(2018 n=9 ; 2019 n=17 ; 2020 n=20)$. The data was taken from the document of thesis examination assessment from three thesis examiners during those periods of time. The matrix of Thesis Assessment is derived from faculty's vision and mission consisting seven points is used to reveal scores of each of them, giving the readers description about the critical thinking level of each student. Those seven points are:

a. Originality and the depth of the problem

b. Systematic of writing

c. Language use

d. The correct research methodology and its application

e. The ability to present material and scientific argument

f. The relevance of the research theory problem and the English Language.

g. The contribution of the research result to the English development studies.

Since not all the points of the matrix focusing the ability of students' critical thinking, the researchers would only use some of them as the way to gather the research data. Those are Originality and the depth of the problem, the ability to present material and scientific argument, the relevance of the research theory problem and the English Language, and the contribution of the research result to the English development studies. To find the students' learning preferences, the researchers conducted the semi-structured interview which focused the question on with whom the students learning best with minimum cost. There are three main points of learning preferences that would be stressed, those are learning with peers, learning with teachers, and learning autonomously. 


\section{FINDINGS AND DISCUSSION}

\section{Findings}

Writing research is significantly urged to be conducted by senior students to develop their abilities to design their own research paper as the requirement to graduate from the university. In designing a qualified research paper, students must be able to manage, lead, and develop the research and its application which are beneficial for humanism and gain national and international recognition. This is in accordance with Indonesian National Qualification Framework (NQF) as part of presidential Regulation Number 8 in 2012 which regulates outline for undergraduate program curriculum and set its learning outcomes on level 6. Thus, students should have proper level of critical thinking which can be acquired by increasing level of reading and text comprehension. Furthermore, doing research would guarantee the development of students' $4 \mathrm{C}$ such as communicating, collaborating, critical thinking, and creativity (Kembara et al., 2018).

Regarding to the extent of the critical thinking revealed from the assessment of thesis examination, some students' characteristics and backgrounds are assumed to have correlation with how well those students conduct, present and defend their argument during the thesis examination. This has been stressed that some factors are age, sociopsychological of motivation and attitude, anxiety, sex, and learning preferences would determine the success of learning. Reward and punishment are proposed to reduce learning anxiety, as it is known that those two factors are assumed to be the most effective external factors to trigger achievement. However another study proposed statement that the reward and punishment to reduce the learning anxiety (Pinem, 2021).

\section{Discussion}

The students who gain below average scores of all points in the matrix of thesis examination would be categorized based on each point as follows:

\section{a. Originality and the depth of the problem}

It is the first point, and it is not arguable as the most important key point when assessors do the assessment of students' paper. One of the researchers of this study was the lecturer of the students used as the source of the data. It is beneficial since the researcher has known the students for some semester during their time in the university, for the elements of the students' learning style, eagerness and spirit to participate during 
class discussion, initiative to state arguments and defend them in front of class. From the scores of students' thesis examinations, it can be revealed that:

Table 1. Students' Lowest Scores on Thesis Originality and Depth of Problem

\begin{tabular}{ccc}
\hline $\mathbf{R}$ & SCORE & SEX \\
\hline R5 & 10 & F \\
R7 & 10 & F \\
\hline R10 & 10 & M \\
\hline R11 & 10 & F \\
\hline R12 & 11 & M \\
\hline R13 & 10 & F \\
\hline R16 & 10 & F \\
\hline R21 & 10 & F \\
\hline R22 & 10 & M \\
\hline R28 & 10 & F
\end{tabular}

It describes us that the gender or sex does not influence the score of originality and the depth of problem, both genders have the same chance to get stucked in developing critical thinking. The maximal score of this point is 15 , but you can see that most of those respondents gained only 10 of maximum; it proves us that the originality becomes thing that is difficult for them to defend. One thing that can be shared to the readers is that all students have spent more than 10 semesters. Based on the government's regulation, undergraduate level can be achieved in four years consisting of 8 semesters. Our government also limits the duration of undergraduate, it is maximum 12 semesters. If students exceed the limit, they can be dropped out. Another consequence, the more time they spend in the undergraduate level, the more money they should prepare for paying the tuition and the living cost. Since the students are approaching the limit time of the study, it forces them to finish the final paper as soon as and as effective as possible. They have limited time to find the research theme, source of research data, appropriate research method, data analysis, and conclusion drawing. Although doing the in-depth reading sources and critically thinking to find research originality and gap would take more time, those students did not allocate sufficient time. As consequence, the research theme they wrote lacked of originality and tends to have no state of the arts. 


\section{b. The ability to present material and scientific argument}

Regarding to this second element of thesis examination, the researchers add learning preferences as the indicator which clarifies the succeed of internalizing and developing the students' critical thinking. Furthermore, teachers should consider more carefully the students' learning preferences. In this study, the researchers categorize the respondents to three criteria of learning preferences, such as autonomous learners, learn with peers, and learn with teachers. It is expected that by categorizing the high and low students' scores on delivering scientific argument to defend their research work, it reveals the most suit learning preferences to develop Critical Thinking.

Related to the most expected learning preferences, the autonomous learning, most teachers are struggling to make the students to learn independently, so that the learning processes are not limited to the classroom context. There is a strong positive relationship between learning autonomy and English language learning, meaning that there is the absent of external helps (Yasmin \& Sohail, 2018), although not every student could adapt to autonomous very well when teachers are intensively activating students' learning autonomy due to the lecturers' learning methods, curriculum implementation, facilities, and learning environment (Foreign \& Gang, 2020; Munirah \& Arif, 2021).

Table 2. Students' ability to present material and scientific argument

\begin{tabular}{cccc}
\hline R & SCORE & SEX & LEARNING PREFERENCES \\
\hline R5 & 20 & F & Learning with teacher \\
\hline R7 & 18 & F & learning with peers \\
\hline R10 & 10 & M & autonomous learner \\
\hline R11 & 20 & F & learning with peers \\
\hline R13 & 20 & F & Learning with teacher \\
\hline R15 & 20 & F & learning with peers \\
\hline R16 & 20 & F & learning with peers \\
\hline R20 & 19 & F & autonomous learner \\
\hline R21 & 20 & F & learning with peers \\
\hline R22 & 18 & M & learning with peers \\
\hline R24 & 20 & F & Learning with teacher \\
\hline R26 & 20 & M & autonomous learner \\
\hline R28 & 20 & F & learning with peers \\
\hline
\end{tabular}


As it has been stated above, gender does not have correlation with the ability to defend the scientific argument, it is more on the learning preferences. It is also supported by the table 3, revealing us that learning with teacher and learning with peers are more beneficial to students compared to the autonomous learning. Once again, autonomous learning would give different level of achievement contextually. It gains more profit in one context, but it might be different when it is applied in different circumstances.

Table 3. Students' Ability to Present Material and Scientific Argument

\begin{tabular}{ccc}
\hline SCORE & SEX & LEARNING PREFERENCES \\
\hline 23 & F & learning with peer \\
\hline 23 & F & autonomous learner \\
\hline 22 & F & learning with peer \\
\hline 22 & F & autonomous learner \\
\hline 24 & F & learning with peer \\
\hline 24 & M & learning with teacher \\
\hline 21 & M & learning with peer \\
\hline 24 & F & autonomous learner \\
\hline 23 & F & autonomous learner \\
\hline 21 & F & autonomous learner \\
\hline 24 & F & learning with peer \\
\hline 23 & F & learning with peer \\
\hline 23 & F & learning with peer \\
\hline 23 & M & learning with peer \\
\hline & & learning with peer \\
\hline
\end{tabular}

\section{CONCLUSIONS AND SUGGESTIONS}

\section{Conclusions}

It has long been assumed that autonomous learning would be the best method to make students learn independently, they might have chances to pick what sources which suit them. The flexibility to pick time and duration to learn would also the autonomous' beneficial. However, the autonomous learning in the context of defending scientific argument during the thesis examination is seemingly less helpful compared to learning with teacher and peers. It is proven by the scores of the exam of the subjects of this research. In this case, teachers and lecturers are obligated to recognize the students' 
learning preferences in order they would gain the better achievement as it is required for them to have the ability to produce things which are critical, original and, scientific.

\section{Suggestions}

This study only focuses on what can be seen from outside, during the teaching and learning processes. It is expected that the more in-depth measuring of the students' elements which direct them to improve critical thinking would be conducted to the greater number of students coming from various disciplines in order to give the better vision and description for teachers. The better descriptions on it would guarantee the successful of teachers' effort to make the students able to think critically in solving problems.

\section{REFERENCES}

Amin, A. M., \& Ardiansyah, R. (2018). Lecturers ' perception on students ' critical thinking skills development and problems faced by students in developing their critical thinking skills. Jurnal Pendidikan Biologi Indonesia, 4(1), 1-10. https://doi.org/10.22219/jpbi.v4i1.5181

Barnaba, H. Y., \& Rahmawan, A. D. (2019). English Writing Problems of Non-English Department Students. Journal of English Teaching and Learning Issues, 2(2), 131. https://doi.org/10.21043/jetli.v2i2.5740

Bashith, A., \& Amin, S. (2017). The Effect of Problem Based Learning on EFL Students' Critical Thinking Skill and Learning Outcome. Al-Ta Lim Journal, 24(2), 93-102. https://doi.org/10.15548/jt.v24i2.271

Carvalho, C., Fíuza, E., Conboy, J., Fonseca, J., Santos, J., Gama, A. P., \& Salema, M. H. (2015). Critical thinking, real life problems and feedback in the sciences classroom. Journal of Turkish Science Education, 12(2), 21-31. https://doi.org/10.12973/tused.10138a

Choi, E., Lindquist, R., \& Song, Y. (2014). Effects of problem-based learning vs. traditional lecture on Korean nursing students' critical thinking, problem-solving, and self-directed learning. Nurse Education Today, 34(1), 52-56. https://doi.org/10.1016/j.nedt.2013.02.012

Dewi, N. (2021). LEAST WE FORGET: INHUMANITY THREATS IN TEACHING IN THE NEW ERA. LLT Journal: A Journal on Language and Language Teaching, 24(1), 117-125. https://doi.org/10.24071/1lt.v24i1.3156

Foreign, ], \& Gang, X. (2020). A Case Study on the Effectiveness of Learner Autonomy in British and American Literature Study. Studies in Literature and Language, 10(1), 
88-94.

http://www.cscanada.net/index.php/sll/article/viewFile/6258/6867\%0Awww.cscan ada.netwww.cscanada.org

Handayani, R. (2016). Students' Critical Thinking Skills in a Classroom Debate. Language and Language Teaching Journal, 19(02), 132-140. https://doi.org/10.24071/1lt.2016.190208

Kembara, M. D., Rozak, R. W. A., \& Hadian, V. A. (2018). Research-based Lectures to Improve Students' 4C (Communication, Collaboration, Critical Thinking, and Creativity) Skills. International Symposium on Social Sciences, Education, and Humanities (ISSEH 2018), January. https://doi.org/10.2991/isseh-18.2019.6

Kumar, R., \& Refaei, B. (2017). Problem-based Learning Pedagogy Fosters Students ' Critical Thinking About Writing. Interdisiplinary Journal of Problem Based Learning, 11(2), 5-10. https://doi.org/http://dx.doi.org/10.7771/1541-5015.1670

Mahanal, S. (2019). RICOSRE : A Learning Model to Develop Critical Thinking Skills for Students with Different Academic Abilities. International Journal of Instruction, 12(2), 417-434. https://doi.org/https://doi.org/10.29333/iji.2019.12227a

Maulidiya, M., \& Nurlaelah, E. (2018). The effect of problem based learning on critical thinking ability in mathematics education. International Conference on Mathematics and Science Education (ICMScE 2018), 1-4. https://doi.org/10.1088/1742$6596 / 1157 / 4 / 042063$

Munirah, \& Arif, M. (2021). Language Learning Preferences in Islamic Higher Education Context. Journal Of English Teaching and Linguistics, 2(1), 1-17.

Nangimah, M. (2020). DEVELOPING ENGINEERING STUDENTS' CRITICAL THINKING FOR PUBLIC SPEAKING THROUGH PROBLEM-BASED LEARNING. LLT Journal: A Journal on Language and Language Teaching, 23(1), 80-88. https://doi.org/doi.org/10.24071/llt.2020.230106

Nappi, J. S. (2017). The importance of Questioning in Developing Critical Thinking Skills. Delta Kappa Gamma Bulletin, 84(1), 30-41.

Nargundkar, S. (2014). A Guided Problem-Based Learning ( PBL ) Approach: Impact on Critical Thinking. 12(2), 91-108.

Nelson, L. P., \& Crow, M. L. (2014). Do Active-Learning Strategies Improve Students' Critical Thinking? Higher Education Studies, 4(2), 77-90. https://doi.org/10.5539/hes.v4n2p77

OCampo, J. M., \& Belecina, R. R. (2018). Effecting Change on Students Critical Thinking in Problem Solving. Educare, 10(2), 109-118.

Pasaribu, T. A., \& Ariyani, Y. (2019). A READER RESPONSE APPROACH IN 
COLLABORATIVE READING PROJECTS TO FOSTER CRITICAL THINKING

SKILLS. LLT Journal: A Journal on Language and Language Teaching, 22(1), 4657. https://doi.org/doi.org/10.24071/1lt.2019.220208

Pinem, Y. A. (2021). Extrinsic Motivation Influencing Vocational Students' English Achievement on Hunting Bule before and during Pandemic. Journal of Physics: Conference Series, 1823(1). https://doi.org/10.1088/1742-6596/1823/1/012015

Yasmin, M., \& Sohail, A. (2018). A creative alliance between learner autonomy and English language learning: Pakistani university teachers' beliefs. Creativity Studies, 11(1), 1-9. https://doi.org/10.3846/23450479.2017.1406874

Yuan, H., Kunaviktikul, W., \& Klunklin, A. (2018). Improvement of nursing students critical thinking skills through problem-based learning in the People's Republic of China: A quasi-experimental study. 10(2008), 70-76. https://doi.org/10.1111/j.1442-2018.2007.00373.xx

Zetriuslita, Ariawan, R., \& Nufus, H. (2016). Students' critical thinking ability: Description based on academic level and gender. Journal of Education and Practice, 7(12), 154-164.

Živkovic, S. (2016). A Model of Critical Thinking as an Important Attribute for Success in the 21st Century. 232(April), 102-108. https://doi.org/10.1016/j.sbspro.2016.10.034 